\title{
Promoting Language Enrichment Activities through Social Learning Platform among Malaysian Gifted Students
}

\section{Zulkarnin Zakaria1, Abu Yazid Abu Bakar ${ }^{2 *}$, Haliza Harun ${ }^{3}$, Mohammad Radzi Manap4, Mahiz Spawi', Mohd Zamrus Mohd Ali' ${ }^{1}$, Ahmad Fuad Mohamad Amin ${ }^{1}$, Rossidi Usop ${ }^{1}$}

${ }^{1}$ Kolej GENIUS Insan, Universiti Sains Islam Malaysia, Nilai, Malaysia

${ }^{2}$ Faculty of Education, Universiti Kebangsaan Malaysia, Bangi, Malaysia

${ }^{3}$ Faculty of Major Language Studies, Universiti Sains Islam Malaysia, Nilai, Malaysia

${ }^{4}$ Language Studies Academy, Universiti Teknologi MARA, Shah Alam, Malaysia

Email: *yazid3338@ukm.edu.my

How to cite this paper: Zakaria, Z., Bakar, A. Y. A., Harun, H., Manap, M. R., Spawi, M., Ali, M. Z. M., Amin, A. F. M., \& Usop, R. (2021). Promoting Language Enrichment Activities through Social Learning Platform among Malaysian Gifted Students. Creative Education, 12, 1805-1817.

https://doi.org/10.4236/ce.2021.128137

Received: July 1, 2021

Accepted: August 3, 2021

Published: August 6, 2021

Copyright $\odot 2021$ by author(s) and Scientific Research Publishing Inc. This work is licensed under the Creative Commons Attribution-NonCommercial International License (CC BY-NC 4.0). http://creativecommons.org/licenses/by-nc/4.0/

\begin{abstract}
This study covers the need to prepare suitable activities for the language enrichment programme for the gifted students. MOOC as a social learning platform for students at the lower secondary is a new approach for the gifted students as they could enrol and go through them at their own pace. This study discovers whether the gifted students could benefit from the language enrichment programme using this social learning platform. An online questionnaire was distributed to all Foundation 1,2 and 3 students of Kolej GENIUS Insan who participated in the pilot programme developed by Open Learning Malaysia. The students also wrote their reflection on the use of MOOC in their journal. Their responses were analysed and reported using descriptive statistics and content analysis. Students acknowledged that the activities were interesting and engaging. They could understand the MOOC instructions easily and clearly. Majority enjoyed peer engagement features such as comments and likes. However, the user interface and navigation were considered tough because students were not used to the platform. They also thought the lessons and activities helped them learn English. The findings revealed the potential of social learning platform to offer flexible learning experience. It could also assist the preparation of suitable materials and activities in a language enrichment programme for gifted students. Teaching and learning process could happen anywhere and anytime providing that students are motivated to complete the activities in the courses. For gifted students, this platform offers independent learning and acceleration at their own pace.
\end{abstract}




\section{Keywords}

Language Learning, Gifted Students, MOOC, Social Learning Platform, Malaysia

\section{Introduction}

Gifted education is known to have a specially developed curriculum that supports the needs and requirements of specially identified group of students who scored high marks in the IQ tests. In many countries, gifted education programme is considered a dedicated effort by the government to help the high IQ students to progress properly under the guidance and supervision of educators at a gifted education institution (VanTassel-Baska \& Brown, 2009; Beecher \& Sweeney, 2008; Worrell et al., 2019). The programme is specially designed to nurture the students' ability in fields normally related to science and technology or STEM subjects. Finding suitable teaching and learning resources for gifted students is a major concern among educators and programme planners and administrators. A large amount of time has been spent on planning and designing suitable contents and activities that would help the students to achieve their full potential.

Gifted students are generally defined as those who performed at a high level in areas like STEM, leadership, arts or language (VanTassel-Baska, 1992; Worrell et al., 2019). So, how do gifted students learn differently from other children? That is the common question that many would ask because gifted students are normally considered as individuals with an aptitude for learning and talent. They are generally seen as students who have mastery in a given field or particular skill and therefore, they require special guidance to enhance their ability and quality for duration of time (VanTassel-Baska, 1992; Gagne, 2005). With a proper plan and supervision from the educators, gifted students are expected to develop and enhance their potentials over a period of time they spend in the special programme. Research has shown that gifted students could learn at a much faster rate, earlier than their peers, have better memories, think abstractly, focus intensely, absorb many stimuli, have stronger empathy and high moral concern (VanTassel-Baska, 1992; Gagne, 2005; Bakar, 2017). There is no such thing as one size fits all concepts in teaching the gifted students because of their uniqueness in the way they think and study a particular topic or subject.

Most gifted programme would stress on the development of students in the STEM subjects (Yu \& Jen, 2020; Tan et al., 2020; Rambo \& Fernandes, 2019; Taber, 2020). At the same time, language subjects are equally important for the students as it would give them the advantage to learn STEM and all other subjects at a faster rate as language competency could enhance their ability to read, comprehend and analyse what they observe, read and listen. The same question 
and challenge exist in preparing and designing suitable materials and activities for their language learning. Language learning today goes beyond the prepared textbooks and traditional teaching and learning materials. With the availability and advancement of current technologies, they might discover a lot of applications and websites developed for language learning activities. There are also many educational platforms to choose from on their mobile devices and laptops. There are free and paid applications to serve the learner's language learning objectives. For more advanced gifted students, they might take their own initiative to explore and discover the world of the internet for materials that suit their interests. Hence, the educators have to take similar effort and experiment to understand the current trends and developments available online to better prepare the materials and activities suitable for the gifted students.

Educators in the gifted programme are expected to prepare suitable contents and activities that could match the high IQ level of students in the programme. There are such established measures taken to guide the educators in the planning and implementation of the programme. There are curriculum compacting, acceleration, enrichment activities and programmes among other things (Olenchak \& Renzulli, 1989; VanTassel-Baska, 2003; VanTassel-Baska \& Brown, 2009). The question remains what would be the most suitable approach in planning and designing the contents and activities for the students to ensure that they would be motivated and interested to engage in the prepared tasks. This paper examines the enrichment activity using an online English course on a social learning platform known as MOOC. Students' involvement and interaction in the SK Open Learning (https://www.skopenlearning.com/) English course were further analysed to answer the research questions set for the study.

This study covers the need to prepare suitable activities for the language enrichment programme for the gifted students (Tan et al., 2020). Making language learning accessible through online social platform for the enrichment activities gifted students is one of the many options available to design authentic social learning environment for the students (Periathiruvadi \& Rinn, 2012). Many gifted students are independent individuals who seek learning opportunities beyond the available textbooks and prepared materials. The introduction of MOOC as a social learning platform for students at the lower secondary is a new approach to offer enrichment materials and activities for the gifted students as they could enrol in the online courses and go through them at their own pace. Thus, this study aims to discover whether the gifted students could benefit from the courses and teachers could develop and enhance MOOC to offer language enrichment programme through this social learning platform. This study has the following research objectives to guide in the planning and designing of the enrichment activity:

1) How do gifted students use online course for their language learning enrichment?

2) How does social learning platform encourage language learning engagement among gifted students? 
Gifted student's identification programme is a crucial phase in the implementation of gifted education programme. Once they are identified and placed in a gifted programme, they would be further grouped according to the criteria set by the institution or school. Kulik and Kulik (1992) had identified a few common groupings of gifted students in the implementation of gifted programmes and adopted throughout the world. Similar approach is taken in the case of the GENIUS gifted programme in Malaysia. Local students would go through the identification phase by sitting for online tests. The students would normally be tested on their cognitive ability and therefore classified based on their IQ level. The following grouping methods have been applied in many gifted programmes and the list below is the guideline adopted for students' grouping based on their ability:

1) Multilevel classes. Similar grade students are divided into groups-often high, middle, and low groups-ability, and the groups are taught in separate classrooms using a standard class timetable.

2) Cross-grade grouping. Students from several grades are formed into groups based on their level of achievement in a subject, and the groups are then taught the subject in separate classrooms regardless of their regular grade placement.

3) Within-class grouping. A teacher forms ability groups within a single classroom and provides each group with instruction appropriate to its level of aptitude.

4) Enriched classes for the gifted and talented. Students who are high in aptitude receive richer, more varied educational experiences than would be available to them in the regular curriculum for their age level.

5) Accelerated classes for the gifted and talented. Students who are high in academic aptitude receive instruction that allows them to proceed more rapidly through their schooling or to finish schooling at an earlier age than other students.

From the suggested grouping of students, educators would normally plan and develop their teaching activities based on the proposed approaches such as enrichment, acceleration and differentiation. For the purpose of this paper, the focus would be on the enrichment approach to the teaching and learning process of the gifted students.

\section{Research Background}

Many gifted students do not receive suitable services to meet their learning needs in the regular classroom (Reis, 2007; Yoon, Kim, \& Koo, 2020). Previous research also reported that more than $70 \%$ of teachers claimed that their brightest students were not challenged or given a chance to further develop in their classrooms (Loveless, Farkas, \& Duffett, 2008). Obviously, educators need to prepare advanced activities because the typical classroom resources are not ready to meet the academic needs of gifted students (Hertberg-Davis \& Callahan, 
2013). The challenges and adaption provided in most of the current gifted institutions are insufficient to meet the needs of the students (Rotigel \& Fello, 2004).

According to Jelinek (2013), enrichment programme is a set of activities and organized pedagogical resources-institutionally and continuously-to complement the standard education. The Enrichment Triad Model is a proposal by Renzulli to serve the gifted students pool, identified by the Revolving Doors model from the conception of giftedness of the Three Ring Theory. This enrichment model is intended to encourage students to increase their productivity through different themes, areas of interest and fields of study (Renzulli \& Reis, 1997). The Renzulli enrichment model comprises three types of enrichment to accommodate different student skills:

1) Type I-general exploratory activities designed to offer a wide variety of activities and experiences so that they can have contact with different areas that are not always covered in the regular curriculum.

2) Type II-creation of new interests based on motivating experiences gained from Type I experiences.

3) Type III-advanced level developed through Type I and II activities, resulting in strong interest in a certain area and intention to dedicate time and effort to deepen their knowledge, seek advanced content and, assume the role of researcher in the learning process.

According to Tan et al. (2020), enrichment is a feature of catering to the learning needs of the gifted students. It aims to meet the needs of the gifted and talented students, foster creativity and develop talents among gifted students, and enhance the quality of the students' learning experiences. Most of the time, the schools and educators who do not have in-depth understandings of the learning needs in practice will face challenges concerning the conceptualization and implementation of such initiative.

In the survey of literature done on technology in gifted education, Periathiruvadi \& Rinn (2012) reviewed past research that had been using various forms of technology in the field of gifted education. They found 24 empirical studies focused on technology and giftedness. Many believe that technology can be used to help gifted students access and perform tasks, but there are a few clear empirical studies on the effects. Information on assistive technologies for gifted students who are twice exceptional (i.e., have cognitive or physical disabilities and gifted) is almost non-existent of the few that were available. Ellsworth (2018) defines assistive technology as technology that helps students reach their full potential, is often associated with children with disabilities. But it has many beneficial functions that can extend to gifted and talented students. It allows for multiple levels of enrichment activities that support classroom instruction and self-pacing curricula. It also provides opportunities for high-level problem solving and collaboration. Assistive technology is an excellent tool for the classroom teacher as well as in the home-based learning environment. Stambaugh and Pierce (2019) listed online coursework as one of the assistive technologies that educators could use 
in their classroom and as an added value to their existing activities for students' enrichment. With the help of online instruction and courses, educators can provide students with the resources needed to continue to learn and develop their expertise. Specially designed online courses for gifted students led by content experts provide for enriched and accelerated opportunities for students.

In addition, research found that when online courses are designed specifically for gifted students, they show greater interest in a learning (Wallace, 2009), advanced problem-solving skills, acquire more in-depth content, and score higher on Advanced Placement exams (Olszewski-Kubilius \& Lee, 2004). Students also reported that the online courses served as a positive way to actively pursue areas of interest in deeper ways, participate in courses not typically offered at their school, to learn at a pace matching their abilities (Olszewski-Kubilius \& Lee, 2004), and to enjoy more personalized instruction not typically found in face-toface settings (Wallace, 2009).

For this particular research, the assistive technology chosen for the enrichment activity was massive online open course (MOOC) developed by OpenLearning Malaysia. The course was known as SK Open Learning online courses that were developed based on the latest KSSM curriculum introduced by the Ministry of Education back in 2017 to replace the old KBSM syllabus. For English language syllabus, CEFR had been adopted as the benchmark in students' level of target proficiency. This pilot study was offered with a few other secondary schools in a few cities around the country. There were open-MOOC and closedMOOC offered to Kolej GENIUS Insan students. The Foundation 1 and 2 students were placed together with all their same grade friends from three different classes known as Abu Bakar, Umar and Uthman. Only the Foundation 3 students from the same grade classes were placed under the open-MOOC course that allowed them to access similar online course offered to other secondary schools who participated in the plot test.

MOOC is a popular social learning platform introduced to the Malaysian public universities since 2015. The Ministry of Higher Education then was working with Open Learning to train the lecturers in public universities to develop their university courses online. Since then, many universities had taken up the challenge to move their courses onto the platform and get students to experience online learning for all the subjects that they enrolled in the university. Lecturers were encouraged to achieve $30 \%$ online presence for every subject they taught. In 2019, this initiative was taken to gauge the effectiveness of MOOC on secondary school students, hence the development of the English courses for Form 1 until 3 in selected schools. Open Learning highlighted the importance of social learning platform as it would present many benefits to the students who enrolled for the courses. The social and learning skills that would help students perform well in their study and online course would be Co-creation, Crowdsourcing, Managing Collaboration, Social Presencing, Self-Expression. In the white paper description, Open Learning illustrated the concept using the self-explanatory diagram in Figure 1. 


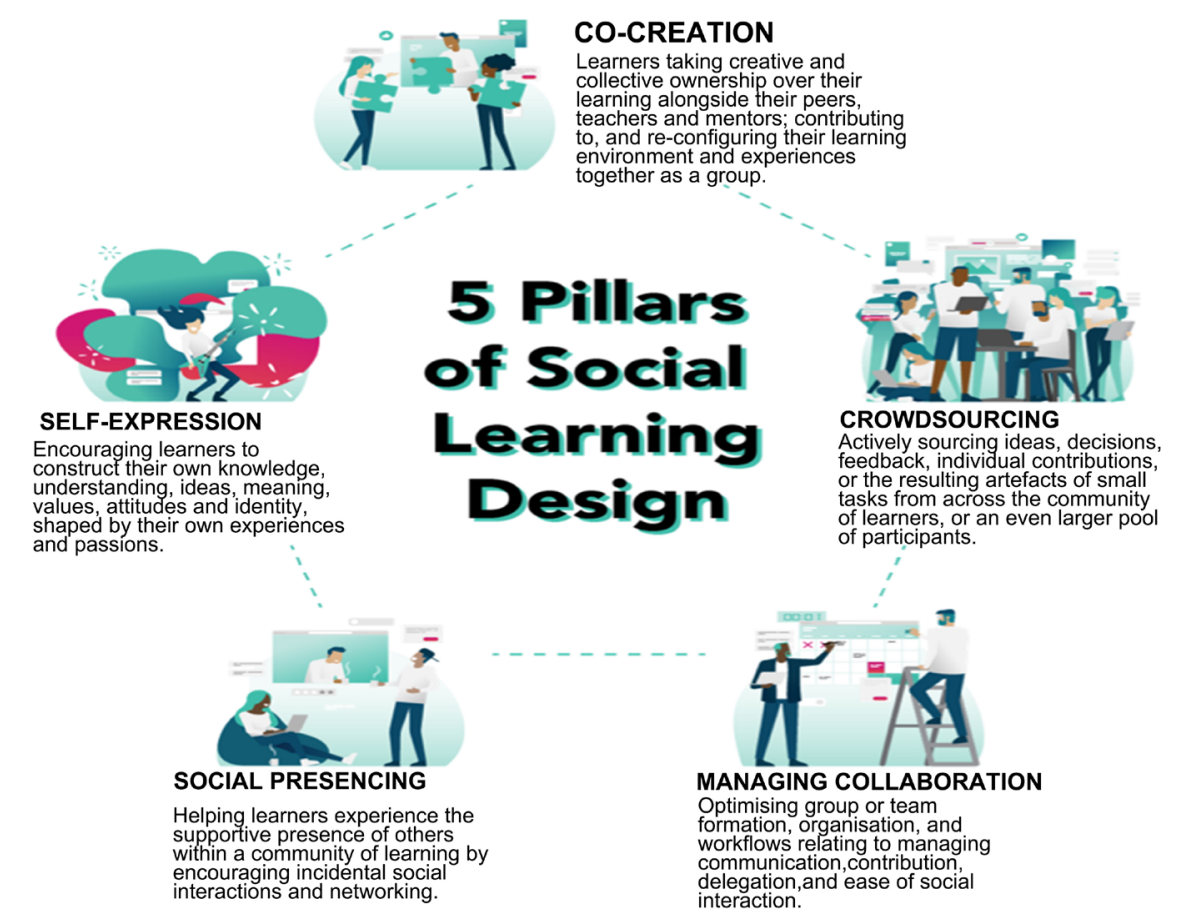

Figure 1. The five pillars of social learning design.

\section{Methodology}

Since the original questionnaire was developed by OpenLearning Malaysia, there were questions developed for the teachers conducting the MOOC courses at their respective schools. The standard online questionnaire was distributed to all Foundation 1 (56), 2 (50) and 3 (48) students of Kolej GENIUS Insan as well as the researchers who participated in the pilot programme developed by Open Learning Malaysia. The questionnaire was given to all students after they had been using the MOOC English courses for one semester in 2019. The students were introduced to the online course back in February and it continued until end of April just before their final examination in May. The students also wrote their reflection on the use of MOOC in their journal. Their responses were analysed and reported using descriptive statistics and content analysis.

\section{Results}

From the feedback, students related that the activities to be interesting and engaging. They could understand the instructions easily and clearly. Majority enjoyed peer engagement features as they could read comments and likes from their peers. However, the user interface and navigation were considered tough to use because students were not used to the look and feeling of the MOOC platform. They also thought the lessons and activities helped them learn English better and they look forward to having new activities to complete in the course.

During the time allocated to use the MOOC, students had been asked to write their opinion, thoughts and feeling on the experiences of using the online courses. The researchers did guide the students, especially those in Foundation 1 
and 2 classes (13 and 14 years old respectively) on how to use the various activities available in the online course. Most of them were first-time users when it comes to using the notebook and managing their work online. It took some time for them to get used to the features on the online course. The first few sessions were spent on getting to know how the MOOC was designed and arranged. Since, the courses were arranged by units in linear order, they were supposed to complete the tasks prepared and achieve the badges for every achievement recorded in the course.

Students were encouraged to interact with their peers and share their online learning activities together. They were moments when some of the advanced students took the initiative to explain certain tasks or activities to their friends. Collaboration was also being reminded among themselves so that no one would feel being left behind. Since they only accessed the course during English subject, they spent roughly around 80 minutes ( 2 periods $\times 40$ minutes). During the weekend, they would also access it online occasionally when they went back home for holiday. When probed further, many would admit that they did not really access the online course when they were at home.

For their reflections in the journal, students were encouraged to write their comments on the contents, social elements, ease of use and language learning experience. They were supposed to write weekly in their journal and sometimes they would skip the entries for those weeks when they had their examination, or they were doing other assignments. Among the common themes found in their journal entries were the positive elements they liked in the MOOC they enrolled. There were many comments written on those activities they did because they "... enjoyed the interactive activities in the online course". To the Foundation 1 and 2 students who were in closed-group MOOC, they like to get live responses from their friends every time they accomplished a task and were rewarded with badges of achievements. Many wrote about the positive encouragement they got from the comments made by the teachers and fellow students. Some said that "... my friends made my day with their live responses. I like thumbs up, love responses and good comments by other students".

Other common themes found in the journal reflection would be students' motivation on continuing the activities prepared in the course. They looked forward to the MOOC online session because they expected to "... find fresh activities every time they used the MOOC". They liked the fact that the contents were "updated weekly and I could do something new" every time. It is "... not so boring compared to our workbook" since many of the language activities would be based on the selected KSSM English workbook chosen by the lecturer. The students admitted that they were motivated to accomplish the tasks given online compared to the one they found in their workbook. Many of the activities were considered new for them since they never had the experience of joining an online course or any MOOC before. The new elements found in the online course were something fresh in their language learning experience. The multi- 
media resources were interesting for them and the group activity feature was as welcoming for them as well. Words like "new" and "interesting" filled up their journal pages and captured the overall mood they shared in their journal.

Finally, most students shared their excitement with the ability to communicate with their friends either from other classes or other schools (for the open MOOC for Foundation 3 students). For the Foundation 1 students, they just registered themselves in the college and still in the process of getting to know their friends from the same batch. Many of the Foundation students did not interact with their friends from other classes and they admitted the excitement of getting to know their friends across the batch. The most excited among the students would be the Foundation 3 students who got the chance to get to interact with outside students. This was a new experience for them because they never contacted anyone from other schools before. Many of them wrote the experiences of communicating with students from other schools who participated in the pilot programme.

\section{Discussion}

The report analysed by OpenLearning was used as a general reflection on the state of MOOC experience shared by students. Even though, there was no specific analysis prepared for Kolej GENIUS Insan, the feedback from the overall pilot study participants was indicative of the overall outcome. There were less than ten schools participated in this study. The overall number of participants was representative of the students in Kolej GENIUS Insan. We have to bear in mind that online courses would be a totally new experience to many students from other participating schools. They might not be properly guided on the various features available in the prepared courses. During the experiment period, many schools were not into online classes just yet. For Kolej GENIUS Insan, the use of laptops and online resources have been part of the teaching and learning process and therefore the researchers believe the questionnaire feedback would be considered as generally positive in those factors analysed.

Based on responses reported in Table 1, most of the responses recorded in the questionnaire indicated more than $50 \%$ positive outlook in the answers given. It should be accepted as generally positive considering that most students were new to MOOC and online courses. From the report, $60 \%$ respondents found the examples used in the lessons were interesting and $53 \%$ of them found the online instructions understandable. Again, the report should be taken on a positive note when majority of the respondents enjoyed the peer engagement features in the course. The social learning element found in the course was encouraging to all. Respondents reported that they liked the social element in the responses to the activities done or completed with students' preference to view others' work instead of having their work viewed. They also enjoyed viewing others' posting online $(86 \%)$. They were also positive in receiving and giving comments and likes (68\%), and they also liked the fact that others can view their posts (53\%). 
Table 1. SK Open Learning questionnaire report.

\begin{tabular}{|c|c|}
\hline MOOC Feature & Responses \\
\hline Contents & $\begin{array}{l}60 \% \text { found the examples used in lessons interesting and } 53 \% \text { found instruc- } \\
\text { tions understandable. }\end{array}$ \\
\hline Social elements & $\begin{array}{l}\text { Majority enjoyed peer engagement features; with a preference to view others' } \\
\text { work instead of having their work viewed: View others post }(86 \%) \text {, receive } \\
\text { and give comments and likes }(68 \%) \text {, others can view their posts }(53 \%) \text {. }\end{array}$ \\
\hline Ease of use & $\begin{array}{l}\text { Generally found navigating UIX a little difficult-not easy to find lesson } \\
(61 \%) \text {, not easy to find activity (54\%), not easy to post on website }(56 \%) \text {. }\end{array}$ \\
\hline Language learning & 51\% think lessons \& activities help them learn English better. \\
\hline
\end{tabular}

However, generally most respondents found navigating the user interface (UIX) a little difficult. They discovered that it was not easy to find lesson online (61\%). Some of them also struggled to find the activity in the unit of lesson (54\%). Some could not even find the correct way to post on the website (56\%). Finally, half of the respondents (51\%) thought the prepared lessons and activities would help them learn English better.

The students' journal reflections were reported to be positive and encouraging as shown in the previous section. Students had shown perceived usefulness of MOOC for their online language learning experience. The MOOC design was suitable for social learning experience as they noted the responses received from their postings, replies and responses gave them the encouragement to be more involved in their lessons. There were reports on enriched experience gained during the online session and this was something that would get from typical face-to-face classes. They also felt more engaged in the lessons they joined online. They had the opportunity to create and have online discussions through such MOOC feature as forums, survey and discussion section in the course. They had enjoyed communication with peers from the same school or outside (for the open MOOC). The new online language learning experience would confirm that social learning is more interesting as it also encouraged students to build relationship with students from other schools. Other elements found to be positive for the students were collaborative language learning and online group activities in solving many tasks given in the online course. The prepared tasks and activities were considered as authentic social engagement for online language learning purposes.

The findings revealed the potential of online courses such as MOOC to offer flexible learning experience. It could also assist teachers and instructional designers to prepare suitable materials and activities that can further improve MOOC as a social learning platform that can be used as a language enrichment programme for the gifted students. Teaching and learning process could happen anywhere and anytime providing that students are motivated to complete the activities in the courses. For gifted students, this platform offers independent learning and acceleration at their own pace. 


\section{Conclusion}

Online learning is going to be a very prominent feature of future education. Online learning platform such as MOOC will be further developed to encourage students to join online courses. The study proves that students were more positive in their language learning experience albeit a virtual one. Language learning should not be boring and an online course such as MOOC has all the potentials to be engaging and entertaining. Language learning would be fun when students are collaborating with their fellow students inside or outside their own institutions. For gifted students, online course offers self-pace learning as well independent learning platform for gifted students (acceleration in learning).

In short, MOOC offers enrichment activities for fast-paced learners; thus, teachers could expect more engagement from students because they are allowed to learn beyond the prescribed textbooks, typical classroom activities and assignments. For future research, it is recommended that the sample population should be expanded to other educational institutions for gifted and talented students in the country. Furthermore, social learning platforms other than MOOC should be considered as methodological tool of the research. These recommendations will enable future researchers to gather richer data which can further contribute to the exploration of the reach's objectives.

\section{Acknowledgements}

The authors are grateful to Faculty of Education, Universiti Kebangsaan Malaysia that had funded the publication of this article via an internal research grant (Code No.: GG-2019-079).

\section{Conflicts of Interest}

The authors declare no conflicts of interest regarding the publication of this paper.

\section{References}

Bakar, A. Y. A. (2017). Developing Gifted and Talented Education Program: The Malaysian Experience. Creative Education, 8, 1-11. https://doi.org/10.4236/ce.2017.81001

Beecher, M., \& Sweeny, S. M. (2008). Closing the Achievement Gap with Curriculum Enrichment and Differentiation: One School's Story. Journal of Advanced Academics, 19, 502-530. https://doi.org/10.4219/jaa-2008-815

Ellsworth, A. (2018). Assistive Technology for Gifted and Talented Students. https://study.com/academy/lesson/assistive-technology-for-gifted-talented-students.ht $\underline{\mathrm{ml}}$

Gagne, F. (2005). From Gifts to Talents: the DMGT as a Developmental Model. In Sternberg, \& Davidson (Eds.), Conceptions of Giftedness (pp. 98-119). Cambridge University Press. https://doi.org/10.1017/CBO9780511610455.008

Hertberg-Davis, H. L., \& Callahan, C. M. (2013). Introduction. In H. L. Hertberg-Davis, \& C. M. Callahan (Eds.), Fundamentals of Gifted Education (pp. 1-10). Routledge.

Jelinek, K. R. (2013). A produção do sujeito de altas habilidades: Os jogos de po- 
der-linguagem nas práticas de seleção e enriquecimento educativo (p. 131). Tese de Doutorado, Educação, Universidade Federal do Rio Grande do Sul.

Kulik, J. A., \& Kulik, C. L. C. (1992). Meta-Analytic Findings on Grouping Programs. Gifted Child Quarterly, 36, 73-77. https://doi.org/10.1177/001698629203600204

Loveless, T., Farkas, S., \& Duffett, A. (2008). High-Achieving Students in the Era of $N C L B$. Thomas B. Fordham Institute.

Olenchak, F. R., \& Renzulli, J. S. (1989). The Effectiveness of the Schoolwide Enrichment Model on Selected Aspects of Elementary School Change. Gifted Child Quarterly, 33, 36-46. https://doi.org/10.1177/001698628903300106

Olszewski-Kubilius, P., \& Lee, S. (2004). Gifted Adolescents' Talent Development through Distance Learning. Journal of Educational Gift, 28, 7-35. https://doi.org/10.1177/016235320402800102

Periathiruvadi, S., \& Rinn, A. N. (2012). Technology in Gifted Education: A Review of Best Practices and Empirical Research. Journal of Research on Technology in Education, 45, 153-169. https://doi.org/10.1080/15391523.2012.10782601

Rambo, M. C. D., \& Fernandes, S. H. A. A. (2019). Proposal of Enrichment Activities for Students with Indicative of High Skills/Giftedness in Mathematics. Acta Scientiae, 21, 128-144.

Reis, S. (2007). No Child Left Bored. School Administrator, 64, 22-26.

Renzulli, J. S., \& Reis, S. M. (1997). The Schoolwide Enrichment Model: A Comprehensive Plan for Educational Excellence. Creative Learning Press.

Rotigel, J., \& Fello, S. (2004). Mathematically Gifted Students: How Can We Meet Their Needs? Gifted Child Today, 27, 46-65. https://doi.org/10.4219/gct-2004-150

Stambaugh, T., \& Pierce, J. (2019). Assistive Technology and the Gifted Learner. In A. Tatnall (Ed.), Encyclopedia of Education and Information Technologies (pp. 1-5). Springer International Publishing. https://doi.org/10.1007/978-3-319-60013-0_150-1

Taber, K. (2020). Enriching School Science for the Gifted Learner. Gatsby Science Enhancement Programme.

Tan, L. S., Ponnusamy, L. D., Lee, S. S., Koh, E., Koh, L., Tan, J. Y. et al. (2020). Intricacies of Designing and Implementing Enrichment Programs for High-Ability Students. Gifted Education International, 36, 130-153.

https://doi.org/10.1177/0261429420917469

VanTassel-Baska, J. (1992). Planning Effective Curriculum for Gifted Learners. Love Publishing.

VanTassel-Baska, J. (2003). Curriculum Planning and Instructional Design for Gifted Learners. Love Publishing.

VanTassel-Baska, J., \& Brown, E. F. (2009). An Analysis of Gifted Education Curriculum Models. In F. A. Karnes, \& S. M. Bean (Eds.), Methods and Materials for Teaching the Gifted (pp. 75-106). Prufrock Press Inc.

Wallace, P. (2009). Distance Learning for Gifted Students: Outcomes for Elementary, Middle, and High School Aged Students. Journal of Educational Gift, 32, 295-320. https://doi.org/10.4219/jeg-2009-855

Worrell, F. C., Subotnik, R. F., Olszewski-Kubilius, P., \& Dixson, D. D. (2019). Gifted Students. Annual Review of Psychology, 70, 551-576.

https://doi.org/10.1146/annurev-psych-010418-102846

Yoon, J., Kim, K. J., \& Koo, K. (2020). Enrichment Program for the Ethnic Minority of Gifted and Talented Students in Science and Engineering, International Journal of Science Education, Part B, 10, 36-50. https://doi.org/10.1080/21548455.2020.1714092 
Yu, H. P., \& Jen, E. (2020). Integrating Nanotechnology in the Science Curriculum for Elementary High-Ability Students in Taiwan: Evidenced-Based Lessons. Roeper Review, 42, 38-48. https://doi.org/10.1080/02783193.2019.1690078 